\title{
Characterization of Nano-Scale Hydroxyapatite Coating Synthesized from Eggshells Through Hydrothermal Reaction on Commercially Pure Titanium
}

\author{
Hsing-Ning $\mathrm{Yu}^{1}{ }^{1}$ Hsueh-Chuan Hsu ${ }^{2}$, Shih-Ching $\mathrm{Wu}^{2}{ }^{2}$, Cheng-Wei Hsu ${ }^{3}$, Shih-Kuang Hsu ${ }^{2}$ \\ and Wen-Fu Ho ${ }^{4, *(D)}$ \\ 1 Department of Surgery, Division of Orthopaedics, Zuoying Branch of Kaohsiung Armed Forces General \\ Hospital, Kaohsiung 81342, Taiwan; david4229@mail.ngh.com.tw \\ 2 Department of Dental Technology and Materials Science, Central Taiwan University of Science and \\ Technology, Taichung 40601, Taiwan; hchsu@ctust.edu.tw (H.-C.H.); scwu@ctust.edu.tw (S.-C.W.); \\ sksheu@ctust.edu.tw (S.-K.H.) \\ 3 Department of Materials Science and Engineering, Da-Yeh University, Changhua 51591, Taiwan; \\ a10019990@gmail.com \\ 4 Department of Chemical and Materials Engineering, National University of Kaohsiung, \\ Kaohsiung 81148, Taiwan \\ * Correspondence: fujii@nuk.edu.tw; Tel.: +886-7-591-9276
}

Received: 12 January 2020; Accepted: 28 January 2020; Published: 28 January 2020

\begin{abstract}
Commercially pure titanium (c.p. Ti) is often used in biomedical implants, but its surface cannot usually combine with the living bone. A coating of hydroxyapatite (HA) on the surface of titanium implants provides excellent mechanical properties and has good biological activity and biocompatibility. For optimal osteocompatibility, the structure, size, and composition of HA crystals should be closer to those of biological apatite. Our results show that the surface of c.p. Ti was entirely covered by rod-like HA nanoparticles after alkali treatment and subsequent hydrothermal treatment at $150{ }^{\circ} \mathrm{C}$ for $48 \mathrm{~h}$. Nano-sized apatite aggregates began to nucleate on HA-coated c.p. Ti surfaces after immersion in simulated body fluid (SBF) for $6 \mathrm{~h}$, while no obvious precipitation was found on the uncoated sample. Higher apatite-forming ability (bioactivity) could be acquired by the samples after HA coating. The HA coating featured bone-like nanostructure, high crystallinity, and carbonate substitution. It can be expected that HA coatings synthesized from eggshells on c.p. Ti through a hydrothermal reaction could be used in dental implant applications in the future.
\end{abstract}

Keywords: commercially pure titanium (c.p. Ti); hydroxyapatite; eggshell; hydrothermal reaction; nanoparticle; simulated body fluid (SBF)

\section{Introduction}

Commercially pure titanium (c.p. Ti) has been used in dentistry, mainly due to its resistance to corrosion, superior biocompatibility, and favorable mechanical properties [1]. However, Ti is regarded as a bioinert metal, which cannot form a chemical bond with bone, and this biological inactivity often results in fibrous tissue surrounding the implanted device [2]. In order to improve both osseointegration rates and longevity of Ti implants, hydroxyapatite (HA) coating could promote the formation of real bonds with the surrounding bone tissue. As previously reported, HA-coated Ti has shown better long-term clinical survival rates than uncoated $\mathrm{Ti}$ due to its chemical similarity with natural bone tissue and its high biocompatibility [3,4]. In order to shorten the surgical healing time of dental implants, a rapid and reliable bonding with the bone is highly desirable. 
Among various surface-coating methods, the plasma spray technique is widely used for coating implants with bioactive ceramics, especially HA coatings. However, there have been problems associated with the poor clinical performances of conventional plasma-sprayed coatings [5]. Therefore, different methods such as electrophoretic deposition, thermal spray deposition, sol-gel coating, and biomimetic coating have been developed to coat Ti implants [6-10]. In particular, the biomimetic apatite coating method is one of the most promising coating technologies, since it can prepare the HA coatings on implant surfaces at a relatively low temperature [6,11]. A bone-like HA coating is formed on a Ti surface by immersing the implant in a Ca-, P-containing solution [11].

In recent years, natural materials such as animal bones, corals, eggshells, and oyster shells have been used to synthesize HA. Wu et al. [12] reported the successful fabrication of HA from oyster shell powder by solid-state reaction and subsequently heat treatment at $900-1100{ }^{\circ} \mathrm{C}$. Recently, our research group [13] proposed an environmentally beneficial and cost-effective method of preparing HA or tri-calcium phosphate (TCP) bioceramics from eggshell biowaste. The eggshell mainly consisted of a major component, i.e., calcium carbonate $(94 \%)$, besides calcium phosphate $(1 \%)$, magnesium carbonate $(1 \%)$, and organic matter (4\%) [14]. It is worth mentioning that the crystal structure and composition of HA prepared from natural sources like eggshells are similar to those of human bones because eggshells notably contain several trace elements ( $\mathrm{Na}, \mathrm{Mg}$, $\mathrm{Sr}$, etc.). Thus, eggshell could be a valuable and promising raw material [15]. In spite of these advantages, there are still few studies concerning ceramic coatings made from natural sources and biowastes. Qaid et al. prepared HA coatings on Ti-6Al-4V substrates using micro-arc oxidation (MAO) in electrolytes at various concentrations of eggshells-derived HA [16]. Roudan et al. used an electrophoretic deposition method to deposit HA from eggshells on a Ti substrate and studied the thermal stability of the resulting coating [17]. Also, eggshells-derived HA was prepared on low-modulus Ti-5Nb-5Mo alloy by hydrothermal heating processing [18].

In this study, we hypothesized that eggshell-derived HA coating, prepared on c.p. Ti surface after alkali treatment, could promote apatite formation and bioactivity. The samples were immersed in simulated body fluid (SBF) for a period of time to evaluate their bioactivity. In order to test this hypothesis, the surface of c.p. Ti was coated with HA by hydrothermal treatment followed by heat treatment in air, using eggshell biowaste as the source of $\mathrm{Ca}$. The hydrothermal reaction could enhance the crystallinity of the product at relatively low temperatures without significantly increase of grain size. The characteristics of the HA coatings after hydrothermal treatment for different periods of time from 0 to $48 \mathrm{~h}$ were then analyzed.

\section{Materials and Methods}

\subsection{Research Material}

C.p. Ti (Grade II) was cut to make plates with the dimension of $5.0 \times 5.0 \times 0.7 \mathrm{~mm}$. The metal surfaces were sanded to the final level using 600-grit paper and then ultrasonically cleaned twice with ethanol and deionized water for $5 \mathrm{~min}$. An alkali treatment, which increased hydrophilicity, was performed by soaking the specimens in $50 \mathrm{~mL}$ solution of $5 \mathrm{M} \mathrm{NaOH}$ at $60^{\circ} \mathrm{C}$ for $24 \mathrm{~h}$. Finally, the samples were ultrasonically cleaned twice in deionized water for 5 min each time and dried in air at $45^{\circ} \mathrm{C}$ for $24 \mathrm{~h}$.

The eggshell powders $(2 \mathrm{~g})$ were put into $15 \mathrm{~mL}$ of deionized water and completely dissolved after adding $5 \mathrm{~mL}$ of hydrochloric acid. The solution was then stirred at $200 \mathrm{rpm}$ for $40 \mathrm{~min}$. A total of $0.85 \mathrm{~mL}$ of $\mathrm{H}_{3} \mathrm{PO}_{4}(85 \%)$ was added dropwise while the mixture was continually stirred for 40 min. The molar $\mathrm{Ca} / \mathrm{P}$ ratio was set to 1.67. $\mathrm{A} \mathrm{NH}_{4} \mathrm{OH}$ solution was added to maintain the $\mathrm{pH}$ of the solution at 10, which resulted in a white HA suspension. Details of this method can be found in some previous works $[12,18]$. The pretreated c.p. Ti samples were placed into the HA suspension and sealed in Teflon-lined stainless-steel autoclaves. The hydrothermal treatments were performed at $150{ }^{\circ} \mathrm{C}$ for 12,24 , and $48 \mathrm{~h}$. The autoclave was allowed to naturally cool to room temperature. After the respective 
periods of reaction, the hydrothermally treated samples were removed, rinsed with deionized water, and dried at $45^{\circ} \mathrm{C}$ in air. The sample without a hydrothermally treated HA coating was used as a control. Finally, all the samples were heat-treated at $500{ }^{\circ} \mathrm{C}$ for $2 \mathrm{~h}$ to increase the crystallinity of the HA coating.

\subsection{Research Methodology}

In this experiment, the samples before and after the heat treatment were placed in deionized water and subjected to ultrasonic vibration at $200 \mathrm{~W}$ for $3 \mathrm{~min}$ to determine the effect of heat treatment on the adhesion between the coating and the substrate [19]. After ultrasonic cleaning, the surface morphology of the coating was observed using field-emission scanning electron microscopy (FE-SEM; JSM-6700F, JEOL, Tokyo, Japan). After the hydrothermal reactions, the samples were immediately immersed in $30 \mathrm{~mL}$ of SBF to examine the bioactivity of the HA-coated c.p. Ti. For comparison purposes, the same immersion test was performed on alkali-treated c.p. Ti without hydrothermal treatment. The bioactivity of all samples was evaluated by soaking the samples in SBF for 6, 12, and 24 $\mathrm{h}$, maintained in a water bath at $37^{\circ} \mathrm{C}$. Reagent-grade chemicals, $\mathrm{NaCl}, \mathrm{NaHCO}_{3}, \mathrm{KCl}, \mathrm{K}_{2} \mathrm{HPO}_{4} \cdot 3 \mathrm{H}_{2} \mathrm{O}$, $\mathrm{MgCl}_{2} \cdot 6 \mathrm{H}_{2} \mathrm{O}, \mathrm{CaCl}_{2}$, and $\mathrm{Na}_{2} \mathrm{SO}_{4}$, were sequentially dissolved in deionized water to prepare $\mathrm{SBF}$, using the method described by Kokubo and Takadama [20]. Table 1 lists the ion concentrations of SBF used in this experiment and that of human blood plasma [20]. The SBF was renewed every 2 days to ensure its fixed ion concentration. At each soaking time point, the samples were taken out, washed with deionized water, and then air-dried. Before and after the various treatments and the soaking in SBF, the c.p. Ti surfaces were analyzed using FE-SEM (JSM-6700F, JEOL, Tokyo, Japan) and X-ray diffractometry (XRD; D8-Discover, BRUKER, Karlsruhe, Germany). The coated surfaces of the specimens were examined using Fourier-transform infrared (FT-IR; FTS-40, Bio-Rad, Cambridge, MA, USA) reflection spectroscopy. After $24 \mathrm{~h}$ of immersion, the chemical surfaces were examined using energy-dispersive X-ray spectroscopy (EDS) attached to an SEM. Changes in weight over the time periods $(6,12$, and $24 \mathrm{~h}$ ) were recorded and calculated according to the dry weight (Ws) of the samples and the original dry weights (Wo) according to the equation:

$$
\text { Weight gain }(\%)=(\text { Ws } / \text { Wo }-1) \times 100 \%
$$

Table 1. Ion concentrations (mM) of simulated body fluid (SBF) used in this experiment and human blood plasma [20].

\begin{tabular}{ccccccccc}
\hline & $\mathbf{N a}^{+}$ & $\mathbf{K}^{+}$ & $\mathbf{M g}^{2+}$ & $\mathbf{C a}^{2+}$ & $\mathbf{C l}^{-}$ & $\mathbf{H P O}_{4}{ }^{2-}$ & $\mathbf{S O}_{4}{ }^{2-}$ & $\mathbf{H C O}_{3}{ }^{-}$ \\
\hline Blood plasma & 142.0 & 5.0 & 1.5 & 2.5 & 103.0 & 1.0 & 0.5 & 27.0 \\
SBF & 142.0 & 5.0 & 1.5 & 2.5 & 147.8 & 1.0 & 0.5 & 4.2 \\
\hline
\end{tabular}

\section{Results}

\subsection{Characterization of Surfaces under Various Treatment Conditions}

Figure 1 shows FE-SEM images of the c.p. Ti surfaces subjected to hydrothermal treatment for 12, 24 , and $48 \mathrm{~h}$. A nanoscale fine network structure, composed of many feather-like, elongated features placed perpendicularly to the surface, formed on the c.p. Ti surface after the initial $\mathrm{NaOH}$ treatment, as shown in Figure 1a. When c.p. Ti was hydrothermally treated at $150{ }^{\circ} \mathrm{C}$, the treatment time had an obvious effect on the formation of nano-HA. Few particles were formed on the c.p. Ti surface after $12 \mathrm{~h}$ (Figure 1b). More rod-like particles were formed and completely covered the surface after treatment time reached 24 and $48 \mathrm{~h}$ (Figure 1c,d). As the time of the hydrothermal reaction increased, the amount and size of the rod-shaped HA particles also increased significantly. 

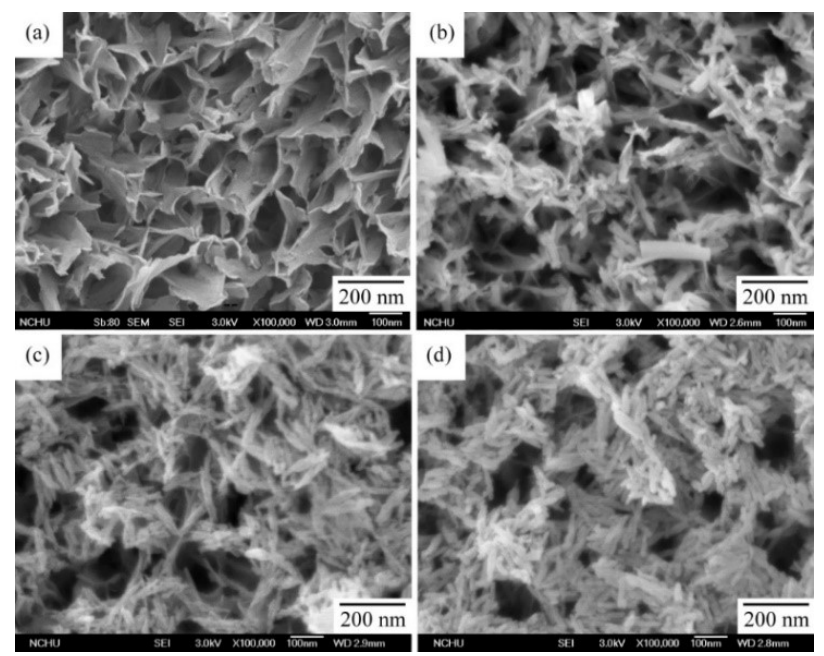

Figure 1. Field-emission scanning electron microscopy (FE-SEM) photographs of the surfaces of commercially pure titanium (c.p. Ti) subjected to hydrothermal treatment at $150{ }^{\circ} \mathrm{C}$ for (a) 0 , (b) 12 , (c) 24 , and (d) $48 \mathrm{~h}$.

Figure 2 shows the SEM images of the non-heat-treated surfaces of the HA-coated c.p. Ti samples and the samples that were heat-treated at $500{ }^{\circ} \mathrm{C}$ for $2 \mathrm{~h}$ in air. After heat treatment, the HA particles still retained a rod-like nanostructure, while the size of the nanoparticles slightly increased to around $90 \mathrm{~nm}$ in length and $23 \mathrm{~nm}$ in width. Figure 3 shows the XRD patterns of the non-heat-treated and heat-treated HA-coated c.p. Ti samples. For the non-heat-treated samples, besides the HA and Ti peaks, only broader peaks could be identified for the surface after $\mathrm{NaOH}$ treatment. After heat treatment at $500{ }^{\circ} \mathrm{C}$ for $2 \mathrm{~h}$, peaks corresponding to the anatase phase of $\mathrm{TiO}_{2}$ were detected, as shown in Figure $3 \mathrm{~b}$.

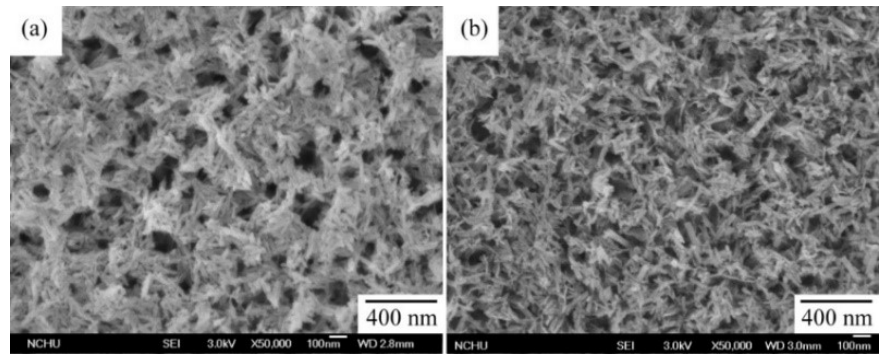

Figure 2. FE-SEM photographs of HA-coated c.p. Ti samples after hydrothermal treatment at $150{ }^{\circ} \mathrm{C}$ for $48 \mathrm{~h}$ : non-heat-treated surface (a) and heat-treated surface at $500{ }^{\circ} \mathrm{C}$ for $2 \mathrm{~h}(\mathbf{b})$.

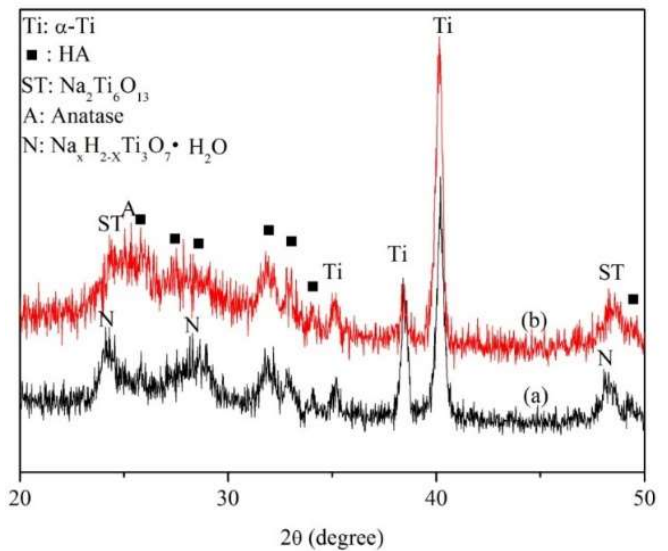

Figure 3. X-ray diffractometry (XRD) patterns of HA-coated c.p. Ti samples after hydrothermal treatment at $150{ }^{\circ} \mathrm{C}$ for $48 \mathrm{~h}$ : non-heat-treated surface (a) and heat-treated surface at $500{ }^{\circ} \mathrm{C}$ for $2 \mathrm{~h}(\mathbf{b})$. 
The FT-IR spectra of the non-heat-treated and heat-treated HA-coated c.p. Ti samples are shown in Figure 4. The non-heat-treated and heat-treated samples had similar FT-IR spectra, indicating that the same functional groups were observed in the HA coatings. Bands assigned to $\mathrm{OH}^{-}, \mathrm{PO}_{4}{ }^{3-}, \mathrm{CO}_{3}{ }^{2-}$, and $\mathrm{H}_{2} \mathrm{O}$ were present. The FT-IR bands also identified the functional groups that are characteristic of carbonate-incorporated HA.

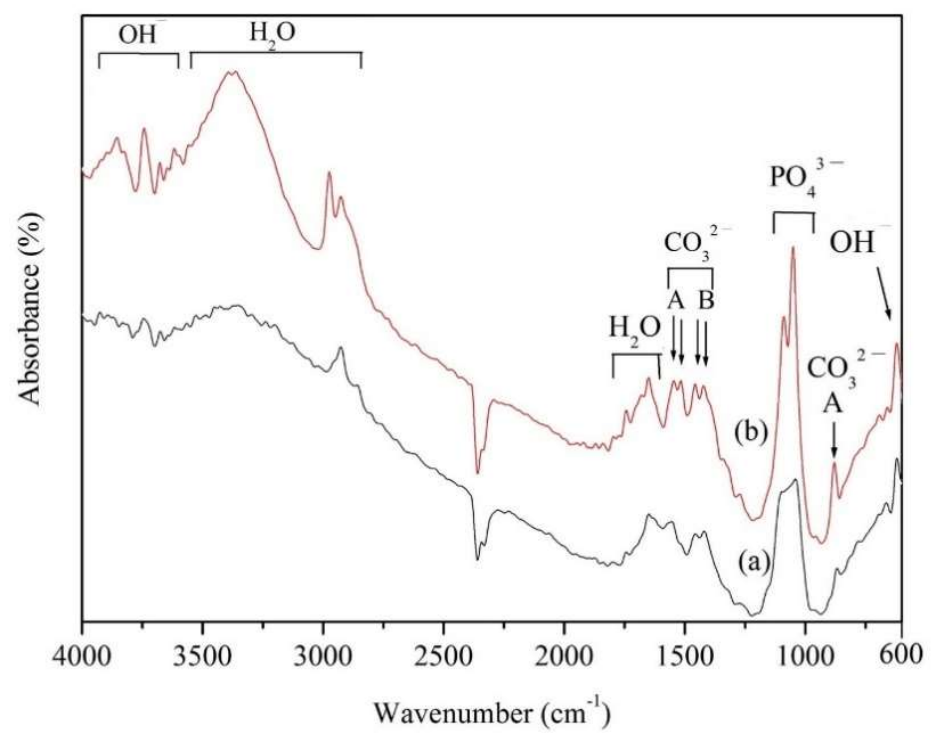

Figure 4. Fourier-transform infrared (FT-IR) spectra of HA-coated c.p. Ti samples after hydrothermal treatment at $150{ }^{\circ} \mathrm{C}$ for $48 \mathrm{~h}$ : non-heat-treated surface (a) and heat-treated surface at $500{ }^{\circ} \mathrm{C}$ for $2 \mathrm{~h}(\mathbf{b})$.

In order to examine the adhesion between the c.p. Ti substrate and the nano-HA layer, both the non-heat-treated and the heat-treated samples were ultrasonically cleaned at $200 \mathrm{~W}$ for $3 \mathrm{~min}$ in deionized water. The experimental results are shown in Figure 5. The coating of the heat-treated sample appeared to be strongly adhesive to the c.p. Ti substrate. The loosely bound HA coating on the non-heat-treated sample was almost completely removed during ultrasonic cleaning, exposing the original alkali-treated surface, while the nano-HA crystals remained intact on the coated surface of the heat-treated samples. Accordingly, the adhesive strength of the HA coating on the surface of the heat-treated samples was relatively high due to heat treatment.

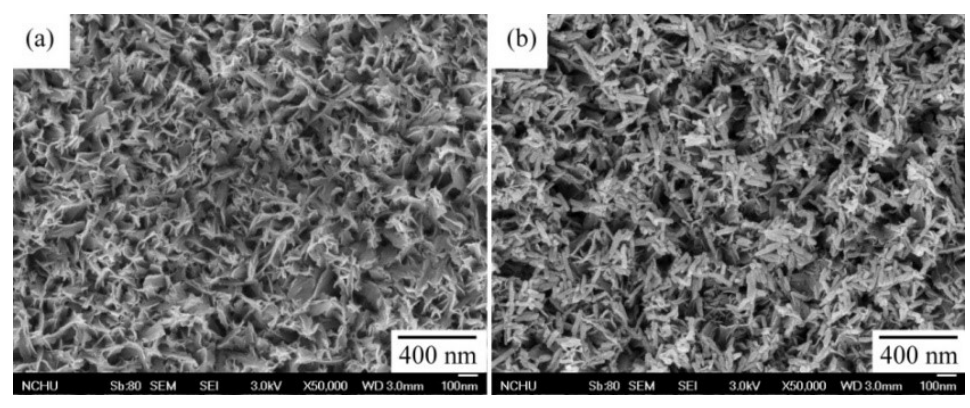

Figure 5. FE-SEM images showing the effect of ultrasonic cleaning on the surface morphology of HA-coated c.p. Ti samples after hydrothermal treatment at $150{ }^{\circ} \mathrm{C}$ for $48 \mathrm{~h}$ : non-heat-treated surface (a) and heat-treated surface at $500{ }^{\circ} \mathrm{C}$ for $2 \mathrm{~h}(\mathbf{b})$.

\subsection{Apatite-inducing Ability of HA-Coated c.p. Ti}

Figure 6 shows FE-SEM micrographs of the surfaces of both $\mathrm{NaOH}$-treated c.p. Ti and HA-coated c.p. Ti that were subjected to heat treatment at $500^{\circ} \mathrm{C}$ for $2 \mathrm{~h}$ after subsequent soaking in SBF for 6,12 , and $24 \mathrm{~h}$. The bioactivity of the HA-coated c.p. Ti was evaluated by examining apatite's formation 
on the surface of the specimens after soaking in SBF. NaOH-treated c.p. Ti without an HA coating was tested for comparison. Nano-sized particles in the form of aggregates were first observed on the HA-coated Ti surface after $6 \mathrm{~h}$ of immersion in SBF, while no obvious precipitation was found on the metal without an HA coating. In contrast, precipitates were observed on the $\mathrm{NaOH}$-treated sample after immersion in SBF for $12 \mathrm{~h}$. In the same immersion period, larger numbers of nano-spherulites were deposited on the HA-coated Ti. Dense, compact, and larger sized round-shaped apatite clusters were formed on the HA-coated Ti samples after only $24 \mathrm{~h}$ of immersion. Conversely, rod-like apatite nanoparticles in a loosely compact film covered the $\mathrm{NaOH}$-treated Ti samples. This study found that the morphology of apatite deposits was closely related to the surface modification conditions and the underlying substrate material and topography.

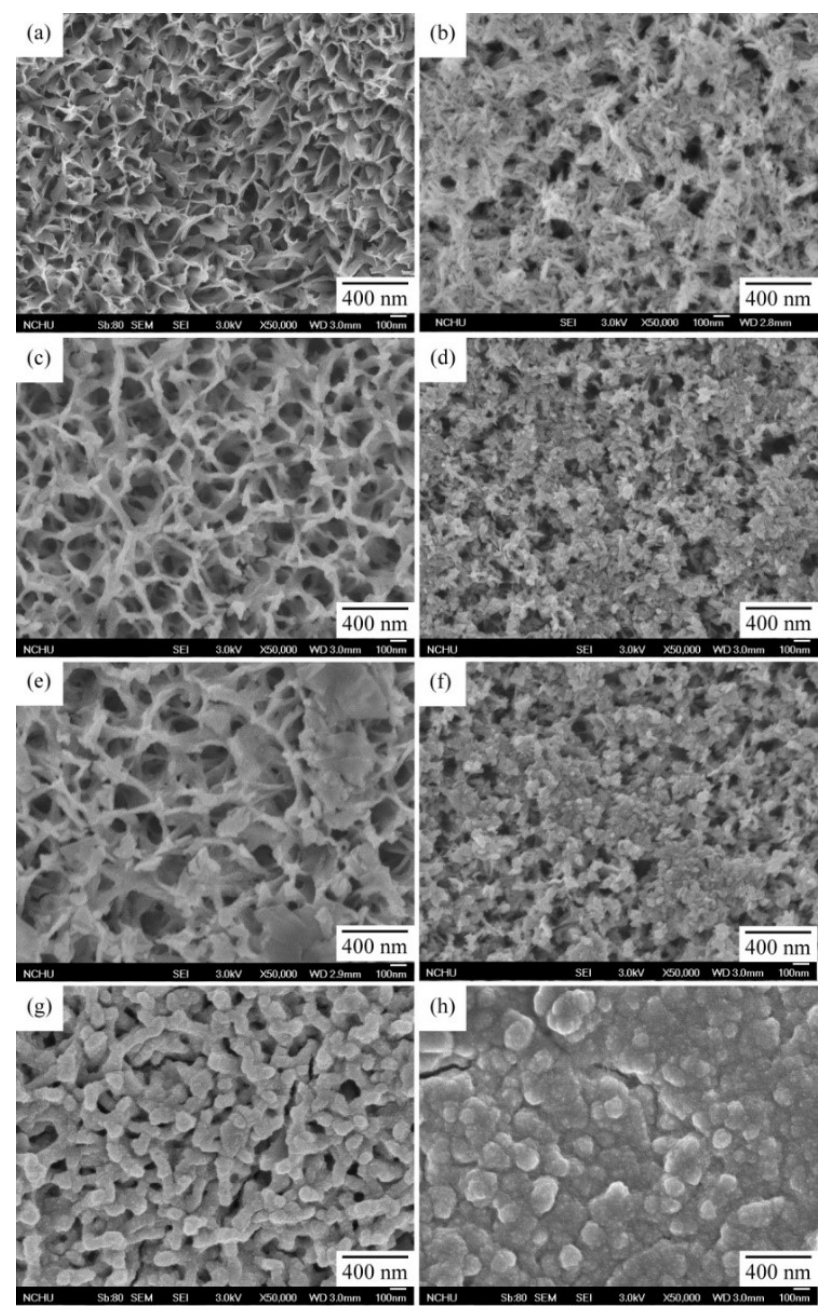

Figure 6. FE-SEM photographs of the surfaces of $\mathrm{NaOH}$-treated c.p. $\mathrm{Ti}(\mathbf{a}, \mathbf{c}, \mathbf{e}, \mathbf{g})$ and HA-coated c.p. Ti samples $(\mathbf{b}, \mathbf{d}, \mathbf{f}, \mathbf{h})$ that were subjected to heat treatment at $500{ }^{\circ} \mathrm{C}$ for $2 \mathrm{~h}$ after subsequent soaking in $\mathrm{SBF}$ for 6,12 and $24 \mathrm{~h}$, respectively.

Figure 7 shows the results of EDS analysis of both $\mathrm{NaOH}$-treated c.p. Ti and HA-coated c.p. Ti that were heat-treated at $500^{\circ} \mathrm{C}$ for $2 \mathrm{~h}$, after subsequent soaking in SBF for $24 \mathrm{~h}$. EDS analysis identified the mineral phase of the depositions on the surfaces of the two groups of samples as mainly composed of calcium and phosphorous, with some magnesium uptaken from the SBF. The results for the HA-coated c.p. Ti before soaking in SBF, used as a control, are shown in Figure 7c. It is clear that the intensities of the $\mathrm{Ca}$ and $\mathrm{P}$ apatite peaks were greater for the HA-coated sample, when compared with those of the control. 

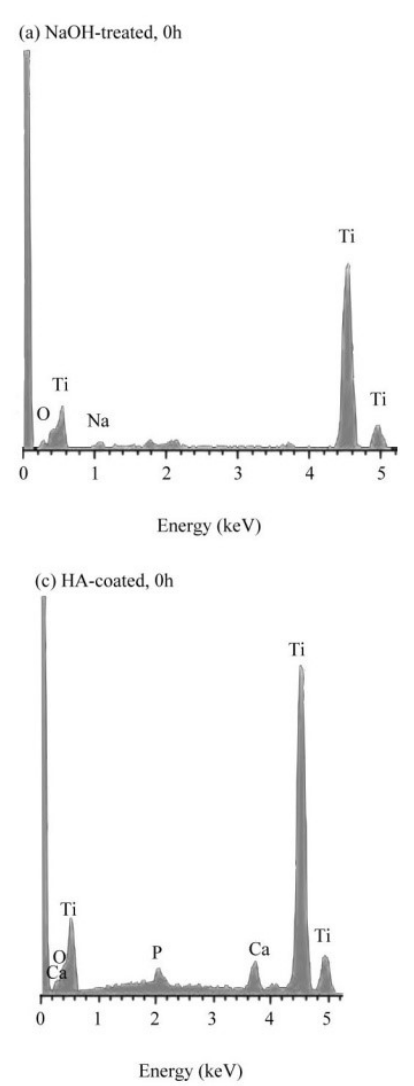
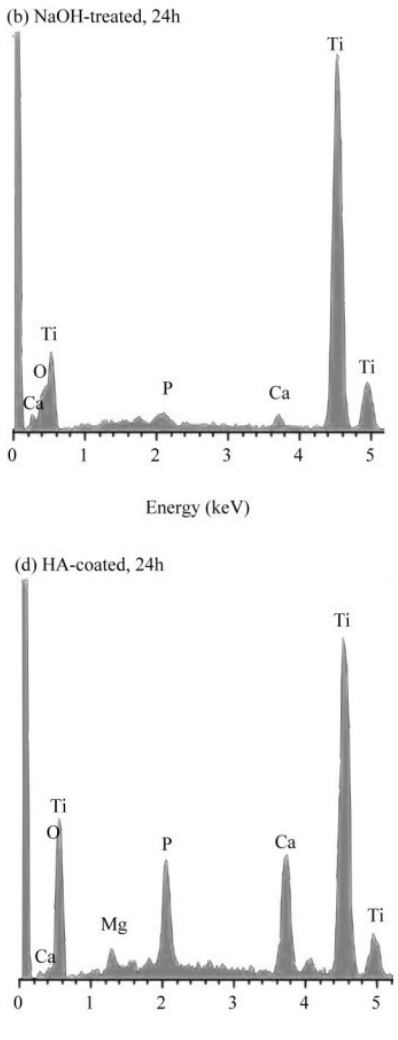

Energy $(\mathrm{keV})$

Figure 7. Energy-dispersive X-ray spectroscopy (EDS) of the surfaces of $\mathrm{NaOH}$-treated c.p. Ti (a,b) and HA-coated c.p. Ti (c,d) subjected to heat treatment at $500^{\circ} \mathrm{C}$ for $2 \mathrm{~h}$ before and after subsequent soaking in SBF for $24 \mathrm{~h}$.

Figure 8 shows the weight change of the apatite deposition on the surfaces of both $\mathrm{NaOH}$-treated c.p. Ti and HA-coated c.p. Ti that were subjected to heat treatment at $500^{\circ} \mathrm{C}$ for $2 \mathrm{~h}$ after subsequent soaking in SBF for 6,12 , and $24 \mathrm{~h}$. The samples were dried at $45^{\circ} \mathrm{C}$ for $24 \mathrm{~h}$ prior to weighing. The weight gain of the apatite deposition increased significantly with the immersion time for both groups. The HA-coated substrate showed an increase in the deposition rate compared with its non-HA-coated counterpart. It was noted that the non-HA-coated substrate showed little or no increase in weight up to $6 \mathrm{~h}$ of immersion in SBF. The result confirmed that the samples with HA coating had a higher apatite-forming ability, which suggests better bioactivity.

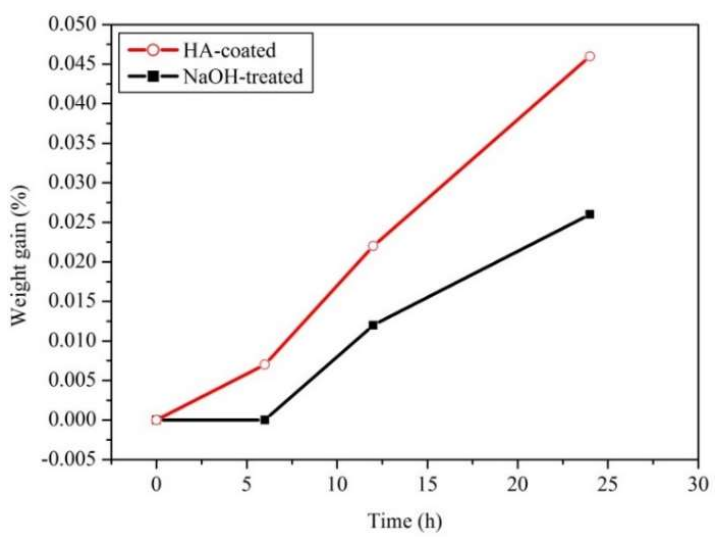

Figure 8. Weight gain as a function of soaking time for the surfaces of $\mathrm{NaOH}$-treated c.p. $\mathrm{Ti}$ and HA-coated c.p. Ti that were subjected to heat treatment at $500^{\circ} \mathrm{C}$ for $2 \mathrm{~h}$ after subsequent soaking for different periods in SBF. 


\section{Discussion}

This study found that the amount and size of rod-shaped HA particles on the c.p. Ti surface increased with the treatment time, from $12 \mathrm{~h}$ to $48 \mathrm{~h}$ (Figure 1). A possible explanation for this result is that, when the hydrothermal reaction time is extended, a large number of hydroxyl groups are promoted on the c.p. Ti surface, which is the key step to initiate the growth of HA on c.p. Ti [21]. The ability to form nano-HA on Ti surface could be promoted by increasing the temperature and time of the hydrothermal treatment. Hu et al. [21] and Nakagawa et al. [22] reported that, when Ti was hydrothermally treated in an $\mathrm{HA}$ suspension solution, negatively charged basic $\mathrm{OH}$ and acidic $\mathrm{OH}$ groups were formed on Ti surface. The abundant Ti-OH groups were negatively charged and could combine with the positively charged ions of $\mathrm{Ca}^{2+}$ in the suspension. As the $\mathrm{Ca}^{2+}$ ions accumulated on the surface, the surface became positively charged and reacted with the negatively charged phosphate ions, thus nucleating HA.

The presence of a rough surface with many micropores on the nano-HA coated samples may effectively enhance the fixation of an implant to bone [23]. After the hydrothermal reaction, the aggregated particles had a tiny rod-like nanostructure with an average length of less than $100 \mathrm{~nm}$. Liu and Webster indicated that nano-HA coatings exhibit enhanced osteoblast cell functions due to the large effective surface area and surface nano-roughness [24]. Therefore, the nano-HA coating prepared by the hydrothermal method is very promising as an application prospect for implant materials. In this study, the c.p. Ti sample hydrothermally treated at $150^{\circ} \mathrm{C}$ for $48 \mathrm{~h}$ with a wholly HA-coated surface was analyzed for its coating characteristics and apatite-forming ability in SBF.

It has been asserted $[25,26]$ that the surface of $\mathrm{Ti}$ forms sodium hydrogen titanate $\left(\mathrm{Na}_{x} \mathrm{H}_{2-\mathrm{x}} \mathrm{Ti}_{3} \mathrm{O}_{7} \cdot \mathrm{H}_{2} \mathrm{O}\right)$ after $\mathrm{NaOH}$ treatment, which is subsequently transformed into sodium titanate $\left(\mathrm{Na}_{2} \mathrm{Ti}_{6} \mathrm{O}_{13}\right)$ and anatase through heat treatment. Also, after heat treatment at $500{ }^{\circ} \mathrm{C}$ for $2 \mathrm{~h}$, peaks corresponding to the anatase phase of $\mathrm{TiO}_{2}$ were detected, as shown in Figure 3. Wang et al. [27] investigated c.p. Ti treated with a $\mathrm{H}_{2} \mathrm{O}_{2} / \mathrm{TaCl}_{5}$ solution at $80{ }^{\circ} \mathrm{C}$ for various times and found that anatase was the primary phase detected in the surface layers after heating between $300^{\circ} \mathrm{C}$ and $600{ }^{\circ} \mathrm{C}$, suggesting that anatase is necessary to trigger early apatite formation in SBF.

In Figure 4, carbonate substituted the $\mathrm{OH}^{-}$(A-type) and phosphate (B-type) groups, which resulted in the transformation of HA into an AB-type carbonated structure. This carbonated HA is similar to bone [28]. The most notable fact is that the FT-IR spectra of the samples reported in Figure 4 resemble those found in previous research [12], in which nano-sized HA powders were prepared with eggshells through a hydrothermal reaction at $150{ }^{\circ} \mathrm{C}$. For both non-heat-treated and heat-treated c.p. Ti samples, the functional group $\mathrm{OH}^{-}$was also found on the surfaces: this is a proven positive factor for bone-like apatite formation [29]. The result indicated that the $\mathrm{OH}^{-}$group formed on the heat-treated c.p. Ti surface seemed to be more abundant, which might be attributed to the formation of the anatase phase after heat treatment at $500{ }^{\circ} \mathrm{C}$. Previous studies have shown that only weakly absorbed $\mathrm{OH}^{-}$ disappears at lower heat-treatment temperatures, while $\mathrm{OH}^{-}$that is strongly bounded with Ti remains on the surface at temperatures up to $600{ }^{\circ} \mathrm{C}$ and more [30,31]. Moreover, it has been observed that only strongly bounded $\mathrm{OH}^{-}$groups are responsible for the bioactivity of Ti surfaces [32,33].

The results of Figure 5 indicated that the adhesive strength of the HA coating was improved after heat treatment. Lu et al. [34] also reported that the adhesive strength of HA/Ag coatings on a Ti substrate was significantly raised after heat treatment. Additionally, a high degree of crystallinity $(86 \%)$ in the HA coating was observed after heat treatment at $500^{\circ} \mathrm{C}$. It is generally believed that crystallinity is the dominant factor for the dissolution of an HA coating [35]. HA coatings with low crystallinity have been shown to be more easily degraded in body fluids, and Hu et al. [36] have also confirmed that more cells are absorbed and proliferate on well-crystallized HA coatings.

In a study by Nishigawa et al., the effect of silica-coated zirconia surfaces on bond strength was also examined by using the ultrasonic cleaning test [37]. In the present study, the adhesion between the c.p. Ti substrate and the HA coating was examined in the non-heat-treated and heat-treated specimens using an ultrasonic washing process in deionized water. Due to the limitations of this test method, 
we could not obtain quantitative data to determine if the coating had sufficient adhesion to survive implantation. In our future research, a micro-scratch tester will be adopted to quantitatively evaluate the adhesion strength of the coating on the substrate.

Due to the chemical and structural similarities to bone and dental minerals, HA exhibits excellent biocompatibility and possesses the ability to stimulate the formation of new bones, which makes it a potential material of choice for coating metals for orthopedic, dental, and other biomedical applications [21]. When the structure, size, and composition of HA crystals are closer to those of biological apatite, optimal osteocompatibility of HA can be achieved [38]. In this study, the features of the HA coatings such as nano-structure, high crystallinity, and carbonate substitution led to coatings exhibiting bone-like structures. Additionally, HA prepared from eggshell powders contains several important trace elements, such as $\mathrm{Na}, \mathrm{Mg}$, and $\mathrm{Sr}$, which play a key role in bone metabolism and cell proliferation [12,39-41].

\section{Conclusions}

In this study, nano-HA coatings on c.p. Ti were successfully developed through a hydrothermal reaction and heat treatment using eggshell biowaste as a source of $\mathrm{Ca}$. When c.p. Ti was hydrothermally treated at $150{ }^{\circ} \mathrm{C}$, the reaction time had an effect on the formation of nano-HA particles. The amount and size of the prepared HA particles increased with the treatment time. The c.p. Ti surface was entirely covered by HA nanoparticles after $48 \mathrm{~h}$, and the aggregated HA particles exhibited a tiny rod-like nanostructure, with an average particle length of less than $100 \mathrm{~nm}$. After subsequent heat treatment, the morphology of the HA particles was retained, while their size slightly increased to around $90 \mathrm{~nm}$ in length and $23 \mathrm{~nm}$ in width. The FT-IR bands identified functional groups that were characteristic of AB-type carbonate-incorporated HA. The HA coating achieved a high degree of crystallinity (86\%) after heat treatment at $500{ }^{\circ} \mathrm{C}$ for $2 \mathrm{~h}$ and strongly adhered to the c.p. Ti substrate. Dense, compact, and larger sized round-shaped apatite granules accumulated on the HA-coated Ti samples after only $24 \mathrm{~h}$ of immersion, while rod-like apatite nanoparticles with a loosely compact film covered the $\mathrm{NaOH}$-treated Ti samples. A higher apatite-forming ability could be acquired by the samples coated with HA, suggesting better bioactivity.

Author Contributions: Conceptualization, W.-F.H., H.-C.H., and S.-C.W.; methodology, W.-F.H., H.-C.H., and S.-C.W.; software, C.-W.H.; validation, W.-F.H. and H.-N.Y.; formal analysis, H.-C.H.; investigation, W.-F.H. and C.-W.H.; resources, W.-F.H., H.-N.Y., and H.-C.H.; data curation, S.-K.H.; writing-original draft preparation, W.-F.H.; writing - review and editing, H.-N.Y.; visualization, S.-K.H.; supervision, H.-N.Y.; project administration, W.-F.H. and H.-N.Y.; funding acquisition, W.-F.H. and H.-N.Y. All authors have read and agreed to the published version of the manuscript.

Funding: Partial financial support for this research was provided by the Zuoying Branch of Kaohsiung Armed Forces General Hospital and National University of Kaohsiung, grant number ZBH 108-09.

Conflicts of Interest: The authors declare no conflicts of interest.

\section{References}

1. Yeo, I.-S.L. Modifications of dental implant surfaces at the microand nano-level for enhanced osseointegration. Materials 2020, 13, 89. [CrossRef] [PubMed]

2. Katta, P.P.K.; Nalliyan, R. Corrosion resistance with self-healing behavior and biocompatibility of Ce incorporated niobium oxide coated 316L SS for orthopedic applications. Surf. Coat. Technol. 2019, 375, 715-726. [CrossRef]

3. Qi, J.; Yang, Y.; Zhou, M.; Chen, Z.; Chen, K. Effect of transition layer on the performance of hydroxyapatite/titanium nitride coating developed on Ti-6Al-4V alloy by magnetron sputtering. Ceram. Int. 2019, 45, 4863-4869. [CrossRef]

4. Kar, A.; Raja, K.S.; Misra, M. Electrodeposition of hydroxyapatite onto nanotubular $\mathrm{TiO}_{2}$ for implant applications. Surf. Coat. Technol. 2006, 201, 3723-3731. [CrossRef]

5. Odhiambo, J.G.; Li, W.G.; Zhao, Y.T.; Li, C.L. Porosity and its significance in plasma-sprayed coatings. Coatings 2019, 9, 460. [CrossRef] 
6. Barrère, F.; van der Valk, C.M.; Meijer, G.; Dalmeijer, R.A.J.; de Groot, K.; Layrolle, P. Osteointegration of biomimetic apatite coating applied onto dense and porous metal implants in femurs of goats. J. Biomed. Mater. Res. B 2003, 67, 655-665. [CrossRef]

7. Aydın, İ.; Bahçepınar, A.İ; Kırman, M.; Çipiloğlu, M.A. HA coating on Ti6Al7Nb alloy using an electrophoretic deposition method and surface properties examination of the resulting coatings. Coatings 2019, 9, 402. [CrossRef]

8. Vilardell, A.M.; Cinca, N.; Garcia-Giralt, N.; Dosta, S.; Cano, I.G.; Nogués, X.; Guilemany, J.M. In-vitro comparison of hydroxyapatite coatings obtained by cold spray and conventional thermal spray technologies. Mater. Sci. Eng. C 2020, 107, 110306. [CrossRef]

9. Boyd, A.R.; Duffy, H.; McCann, R.; Meenan, B.J. Sputter deposition of calcium phosphate/titanium dioxide hybrid thin films. Mater. Sci. Eng. C 2008, 28, 228-236. [CrossRef]

10. Azari, R.; Rezaie, H.R.; Khavandi, A. Investigation of functionally graded $\mathrm{HA}-\mathrm{TiO}_{2}$ coating on Ti-6Al-4V substrate fabricated by sol-gel method. Ceram. Int. 2019, 45, 17545-17555. [CrossRef]

11. Qu, H.; Wei, M. The effect of temperature and initial $\mathrm{pH}$ on biomimetic apatite coating. J. Biomed. Mater. Res. B 2008, 87, 204-212. [CrossRef] [PubMed]

12. Wu, S.C.; Tsou, H.K.; Hsu, H.C.; Hsu, S.K.; Liou, S.P.; Ho, W.F. A hydrothermal synthesis of eggshell and fruit waste extract to produce nanosized hydroxyapatite. Ceram. Int. 2013, 39, 8183-8188. [CrossRef]

13. Wu, S.C.; Hsu, H.C.; Wu, Y.N.; Ho, W.F. Hydroxyapatite synthesized from oyster shell powders by ball milling and heat treatment. Mater. Character. 2011, 62, 1180-1187. [CrossRef]

14. Balasubramanian, V.; Daniel, T.; Henry, J.; Sivakumar, G.; Mohanraj, K. Electrochemical performances of activated carbon prepared using eggshell waste. S. N. Appl. Sci. 2020, 2, 127. [CrossRef]

15. Boutinguiza, M.; Pou, J.; Comesaña, R.; Lusquiños, F.; de Carlos, A.; León, B. Biological hydroxyapatite obtained from fish bones. Mater. Sci. Eng. C 2012, 32, 478-486. [CrossRef]

16. Qaid, T.H.; Ramesh, S.; Yusof, F.; Basirun, W.J.; Ching, Y.C.; Chandran, H.; Krishnasamy, S. Micro-arc oxidation of bioceramic coatings containing eggshell-derived hydroxyapatite on titanium substrate. Ceram. Int. 2019, 45, 18371-18381. [CrossRef]

17. Roudan, M.A.; Ramesh, S.; Wong, Y.H.; Chandran, H.; Krishnasamy, S.; Teng, W.D.; Bang, L.T. Sintering behavior and characteristic of bio-based hydroxyapatite coating deposited on titanium. J. Ceram. Proc. Res. 2017, 18, 640-645.

18. Hsu, H.C.; Wu, S.C.; Hsu, S.K.; Hsu, C.W.; Ho, W.F. Bone-like nano-hydroxyapatite coating on low-modulus Ti-5Nb-5Mo alloy using hydrothermal and post-heat treatments. Thin Solid Films 2019, 687, 137463. [CrossRef]

19. Wu, X.; Weng, D.; Zhao, S.; Chen, W. The deposition of $\gamma-\mathrm{Al}_{2} \mathrm{O}_{3}$ layers on ceramic and metallic supports for the preparation of structured catalysts. Surf. Coat. Technol. 2005, 190, 434-439. [CrossRef]

20. Kokubo, T.; Takadama, H. How useful is SBF in predicting in vivo bone bioactivity? Biomaterials 2006, 27, 2907-2915. [CrossRef]

21. Hu, X.; Shen, H.; Cheng, Y.; Xiong, X.; Wang, S.; Fang, J.; Wei, S. One-step modification of nano-hydroxyapatite coating on titanium surface by hydrothermal method. Surf. Coat. Technol. 2010, 205, 2000-2006. [CrossRef]

22. Nakagawa, M.; Zhang, L.; Udoh, K.; Matsuya, S.; Ishikawa, K. Effects of hydrothermal treatment with $\mathrm{CaCl}_{2}$ solution on surface property and cell response of titanium implants. J. Mater. Sci. Mater. Med. 2005, 16, 985-991. [CrossRef] [PubMed]

23. Habibovic, P.; Yuan, H. 3D microenvironment as essential element for osteoinduction by biomaterials. Biomaterials 2005, 26, 3565-3575. [CrossRef] [PubMed]

24. Liu, H.; Webster, T.J. Nanomedicine for implants: A review of studies and necessary experimental tools. Biomaterials 2007, 28, 354-369. [CrossRef] [PubMed]

25. Hsu, H.C.; Wu, S.C.; Hsu, S.K.; Chuang, S.H.; Ho, W.F. Surface modification of commercially pure Ti treated with aqueous $\mathrm{NaOH}$ treatment and ethyl alcohol aging. J. Med. Biol. Eng. 2013, 33, 331-336. [CrossRef]

26. Yamaguchi, S.; Takadama, H.; Matsushita, T.; Nakamura, T.; Kokubo, T. Preparation of bioactive $\mathrm{Ti}-15 \mathrm{Zr}-4 \mathrm{Nb}-4 \mathrm{Ta}$ alloy from $\mathrm{HCl}$ and heat treatments after an $\mathrm{NaOH}$ treatment. J. Biomed. Mater. Res. A 2011, 97, 135-144. [CrossRef]

27. Wang, X.-X.; Hayakawa, S.; Tsuru, K.; Osaka, A. Improvement of the bioactivity of $\mathrm{H}_{2} \mathrm{O}_{2} / \mathrm{TaCl}_{5}$-treated titanium after subsequent heat treatment. J. Biomed. Mater. Res. 2000, 52, 171-176. [CrossRef]

28. Kunze, J.; Müller, L.; Macak, J.M.; Greil, P.; Schmuki, P.; Müller, F.A. Time-dependent growth of biomimetic apatite on anodic $\mathrm{TiO}_{2}$ nanotubes. Electrochim. Acta 2008, 53, 6995-7003. [CrossRef] 
29. Li, P.; Ohtsuki, C.; Kokubo, T.; Nankanishi, K.; Soga, N. The role of hydrated silica, titania, and alumina in inducing apatite on implants. J. Biomed. Mater. Res. 1994, 28, 7-15. [CrossRef]

30. Busca, G.; Sausey, H.; Saur, O.; Lavalley, J.C.; Lorenzelli, V. FT-IR characterization of the surface acidity of different titanium dioxide anatase preparations. Appl. Catal. 1985, 14, 245-260. [CrossRef]

31. Martra, G. Lewis acid and base sites at the surface of microcrystalline $\mathrm{TiO}_{2}$ anatase: Relationships between surface morphology and chemical behaviour. Appl. Catal. A 2000, 200, 275-285. [CrossRef]

32. Lu, X.; Wang, Y.; Yang, X.; Zhang, Q.; Zhao, Z.; Wenig, L.T.; Leng, Y. Spectroscopic analysis of titanium surface functional groups under various surface modification and their behaviours in vitro and in vivo. $J$. Biomed. Mater. Res. A 2008, 84, 523-534. [CrossRef] [PubMed]

33. Lu, X.; Zhang, H.P.; Leng, Y.; Fang, L.; Qu, S.; Feng, B.; Weng, J.; Huang, N. The effects of hydroxyl groups on Ca adsorption on rutile surface: A first-principles study. J. Mater. Sci. Mater. Med. 2010, 21, 1-10. [CrossRef] [PubMed]

34. Lu, X.; Zhang, B.; Wang, Y.; Zhou, X.; Weng, J.; Qu, S.; Feng, B.; Watari, F.; Ding, Y.; Leng, Y. Nano-Ag-loaded hydroxyapatite coatings on titanium surfaces by electrochemical deposition. J. R. Soc. Interface 2011, 8, 529-539. [CrossRef]

35. Sun, L.; Berndt, C.C.; Khor, K.A.; Cheang, H.N.; Gross, K.A. Surface characteristics and dissolution behavior of plasma-sprayed hydroxyapatite coating. J. Biomed. Mater. Res. 2002, 62, 228-236. [CrossRef]

36. Hu, Q.; Tan, Z.; Liu, Y.; Tao, J.; Cai, Y.; Zhang, M.; Pan, H.; Xu, X.; Tang, R. Effect of crystallinity of calcium phosphate nanoparticles on adhesion, proliferation, and differentiation of bone marrow mesenchymal stem cells. J. Mater. Chem. 2007, 17, 4690-4698. [CrossRef]

37. Nishigawa, G.; Maruo, Y.; Irie, M.; Oka, M.; Yoshihara, K.; Minagi, S.; Nagaoka, N.; Yoshida, Y.; Suzuki, K. Ultrasonic cleaning of silica-coated zirconia influences bond strength between zirconia and resin luting material. Dent. Mater. J. 2008, 27, 842-848. [CrossRef]

38. Barbosa, M.C.; Messmer, N.R.; Brazil, T.R.; Marciano, F.R.; Lobo, A.O. The effect of ultrasonic irradiation on the crystallinity of nano-hydroxyapatite produced via the wet chemical method. Mater. Sci. Eng. C 2013, 33, 2620-2625. [CrossRef]

39. Ho, W.F.; Hsu, H.C.; Hsu, S.K.; Hung, C.W.; Wu, S.C. Calcium phosphate bioceramics synthesized from eggshell powders through a solid state reaction. Ceram. Int. 2013, 39, 6467-6473. [CrossRef]

40. Boanini, E.; Gazzano, M.; Bigi, A. Ionic substitutions in calcium phosphates synthesized at low temperature. Acta Biomater. 2010, 6, 1882-1894. [CrossRef]

41. Rude, R.K.; Gruber, H.E. Magnesium deficiency and osteoporosis: Animal and human observations. J. Nutr. Biochem. 2004, 15, 710-716. [CrossRef] [PubMed]

(C) 2020 by the authors. Licensee MDPI, Basel, Switzerland. This article is an open access article distributed under the terms and conditions of the Creative Commons Attribution (CC BY) license (http://creativecommons.org/licenses/by/4.0/). 